MODELS OF SCIENCE TEACHER PREPARATION 


\section{Science \& Technology Education Library}

\section{VOLUME 13}

\section{SERIES EDITOR}

Ken Tobin, University of Pennsylvania, Philadelphia, USA

\section{EDITORIAL BOARD}

Dale Baker, Arizona State University, Tempe, USA

Beverley Bell, University of Waikato, Hamilton, New Zealand

Reinders Duit. University of Kiel, Germany

Mariona Espinet, Universitat Autonoma de Barcelona, Spain

Barry Fraser, Curtin University of Technology, Perth, Australia

Olugbemiro Jegede, The Open University, Hong Kong

Reuven Lazarowitz, Technion, Haifa, Israel

Wolff-Michael Roth, University of Victoria, Canada

Tuan Hsiao-lin, National Changhua University of Education, Taiwan

Lilia Reyes Herrera, Universidad Autónomade Colombia, Bogota, Colombia

\section{SCOPE}

The book series Science \& Technology Education Library provides a publication forum for scholarship in science and technology education. It aims to publish innovative books which are at the forefront of the field. Monographs as well as collections of papers will be published. 


\title{
Models of Science Teacher Preparation
}

Theory into Practice

\author{
Edited by \\ DERRICK R. LAVOIE \\ Virtual Institute for Teaching and Learning Science, \\ Paso Robles, CA, U.S.A. \\ and \\ WOLFF-MICHAEL ROTH \\ University of Victoria, \\ Victoria, BC, Canada
}

\section{KLUWER ACADEMIC PUBLISHERS}


eBook ISBN: $\quad 0-306-47230-9$

Print ISBN: $\quad$ 0-792-37129-1

(C2002 Kluwer Academic Publishers

New York, Boston, Dordrecht, London, Moscow

All rights reserved

No part of this eBook may be reproduced or transmitted in any form or by any means, electronic, mechanical, recording, or otherwise, without written consent from the Publisher

Created in the United States of America

Visit Kluwer Online at:

http://www.kluweronline.com

and Kluwer's eBookstore at:

http://www.ebooks.kluweronline.com 


\section{CONTENTS}

Introduction

Wolf-Michael Roth \& Derrick Lavoie

SECTION ONE: COLLABORATION AND APPRENTICESHIP MODELS

1. Becoming-in-the-Classroom: Learning to teach in/as Praxis

Wolff-Michael Roth

2. TEAMS: A Science Learning and Teaching Apprenticeship Model

Constance P. Hargrave \& Ann D. Thompson

3. A Problem-Based Learning Approach to Science Teacher Preparation RaymondF. Peterson \& David F. Treagust

4. Linking Schools and Universities in Partnership for Science Teacher Preparation

Marcia K. Fetters \& Paul Vellom

5. The Dynamics of Collaboration in a State-Wide Professional Development Program for Science Teachers

James P. Barufaldi \& Judy Reinhartz

\section{SECTION TWO: SPECIAL ISSUES-DRIVEN MODELS}

6. Instructional Congruence to Promote Science Learning and Literacy Development for Linguistically Diverse Students

Okhee Lee \& Sandra H. Fradd

7. Gender Equity and Science Teacher Preparation

Léonnie J. Rennie

8. Assessment Models that Integrate Theory and Best Practice Mary Stein

9. New Technologies and Science Teacher Preparation

Derrick R. Lavoie

10. Preparing New Teachers for Integrated-Science Classrooms Robert E. Yager, Sandy Enger, \& Ann Guilbert

11. Critical Multiculturalism and Science Teacher Education Programs

Norman Thomson, Margaret Wilder, \& Mary M. Atwater

Portraits of Professional Development Models in Science Teacher

Education: A Synthesis of Perspectives and Issues

Thomas R. Koballa, Jr. \& Debora J. Tippins

Index 


\section{ACKNOWLEDGMENTS}

First and foremost, I wish to thank the chapter authors for outstanding perseverance through many drafts, internal chapter reviews, and discussions. I am particularly grateful for the instrumental support and assistance of co-editor, Michael Roth. I sincerely wish to thank those who provided critical reviews for the authors including: Ronald Anderson, Angela Barton, Ronald Bonnstetter, John Cannon, John Craven, Jim Ellis, Gerald Foster, Dorothy Gabel, James Gallagher, Jack Gerlovich, David Kumar, Norm Lederman, Cheryl Mason, Michael Matthews, Rena Norby, John Penick, and Larry Yore. I give special thanks to Ken Tobin who provided guidance and support throughout all phases of the project and to the reviewers of original outline and subsequent draft manuscript who helped us in shaping this book. Lastly, I dedicate this work to my family for their continual motivation and love during this venture.

Derrick Lavoie, April 2001 